\title{
Fylgikvillar við keisaraskurði
}

\section{Heiðdís Valgeirsdóttir ${ }^{1}$ læknir \\ Hildur Harðardóttir \\ fæðinga- og kvensjúkdómalæknir ${ }^{1,2}$ \\ Ragnheiður I. Bjarnadóttir ${ }^{1,2}$ \\ fæðinga- og kvensjúkdómalæknir}

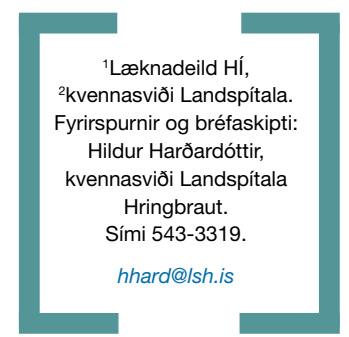

\section{Ágrip}

Inngangur: Tilgangur rannsóknarinnar var að kanna tíðni fylgikvilla við keisaraskurði á Landspítala og bera saman við tíðni erlendis. Skoðaðir voru fylgikvillar sem upp komu í aðgerð eða á fyrstu dögum eftir fæðingu.

Efniviður og aðferðir: Pýði rannsóknarinnar var konur sem fæddu með keisaraskurði á Landspítala frá 1. júlí 2001 til 31. desember 2002. Upplýsingum um aðgerð og feril sjúklings í kjölfarið var safnað á afturvirkan hátt úr mæðraskrá og sjúkraskrám spítalans.

Niðurstöður: Á tímabilinu var framkvæmdur 761 keisaraskurður. Heildartíðni fylgikvilla var 35,5\%. Algengustu fylgikvillarnir voru blóðtap $\geq 1000$ $\mathrm{ml}(16,5 \%)$, hiti í sængurlegu $(12,2 \%)$, rifa niður frá legskurði $(7,2 \%)$ og pörf fyrir blóðgjöf $(4,3 \%)$. Blóðgjöf var oftast pörf eftir bráðakeisaraskurð á 2. stigi fæðingar eftir að áhaldafæðing hafði verið reynd (20\%) og hiti í sængurlegu og rifa frá legskurði voru algengust eftir bráðakeisaraskurð á 2. stigi fæðingar án áhaldafæðingar $(19,4 \%)$. Allir pessir fylgikvillar voru sjaldgæfastir við valkeisaraskurð. Ekki var tölfræðilega marktækur munur á öðrum fylgikvillum eftir pví við hvaða aðstæður aðgerð var gerð.

Ályktanir: Fylgikvillar í kjölfar fæðingar með keisaraskurði eru algengir, einkum ef fæðing er langt á veg komin. Mikilvægt er að vega og meta á einstaklingsgrunni ábendingu fyrir aðgerð og upplýsa sjúkling á viðeigandi hátt.

\section{Inngangur}

Undanfarna áratugi hefur tíðni keisaraskurða aukist jafnt og pétt hér á landi sem og annars staðar. Árið 1950 var tíðni fæðinga með keisaraskurði hér á landi um 1\% en árið 2006 um 17,5\% og hefur verið nánast óbreytt síðastliðinn áratug. ${ }^{1}$ Ýmsar orsakir liggja að baki aukinni tíðni keisaraskurða. Á pessum tíma hafa skurðaðgerðir almennt orðið öruggari til dæmis vegna bætts aðgengis að blóði og blóðhlutum, með tilkomu betri sýklalyfja, vegna framfara við deyfingar og svæfingar og pví er skurðaðgerð í hugum almennings almennt talin mun léttvægari en áður var. Aukin tíðni fjölburafæðinga, hærra hlutfall frumbyrja og síðast en ekki síst, hærra hlutfall fæðandi kvenna með ör í legi eftir fyrri keisaraskurð hefur átt sinn pátt í að auka tíðni keisaraskurða. Á síðustu árum hefur aukist að konur óski eftir fæðingu með valkeisaraskurði án pess að læknisfræðileg ábending sé til staðar. Oftast er ósk um fæðingu með valkeisaraskurði komin til vegna erfiðrar reynslu af fyrri fæðingu en getur einnig verið sprottin af ótta við hefðbundna fæðingu og pann sársauka sem fylgir og vegna hræðslu við að skaða grindarbotn með truflun á starfsemi blöðru og ristils, auk áhyggna af pví að fæðing um leggöng geti haft neikvæð áhrif á kynlíf., 3 Erlendis eru algengustu ástæður fæðingar með valkeisaraskurði fyrri fæðing með keisaraskurði, sitjandastaða fósturs, ósk móður og fyrirsæt fylgja en algengustu ástæður bráðakeisaraskurða eru fósturstreita eða tepptur framgangur á 1 . eða 2. stigi fæðingar. ${ }^{4}$

Rannsóknir hafa sýnt að tíðni fylgikvilla við keisaraskurði sé um 21,4-35,7\%. ${ }^{5,} 6$ Helstu fylgikvillar eru hiti eftir aðgerð, sýking í skurðsári, sýking í legi, blóðmissir >1000ml, pörf á blóðgjöf og pvagfærasýking. ${ }^{5-12}$ Dæmi um sjaldgæfa en alvarlega fylgikvilla eru legnám í kjölfar keisaraskurðar, segamyndun í bláæðum og blóðrek í lungum. ., 6, 12-14 Ýmsir pættir geta haft áhrif á fylgikvilla, svo sem lengd meðgöngu, ofpyngd móður, hár aldur móður og einnig skiptir máli hver ábending var fyrir aðgerðinni. ${ }^{5,12}$ Tíðni fylgikvilla hefur reynst vera lægri við valkeisaraskurði en bráðakeisaraskurði. ${ }^{12,13}$ Í einstaka tilvikum getur reynst nauðsynlegt að gera T-skurð í leg (lóðréttan skurð í miðlínu upp frá láréttum skurði í legi), svo sem ef neðri hluti legs er illa proskaður eins og oft er við fyrirburafæðingu eða barn er í pverlegu og legvatn farið. Slíkt inngrip getur haft í för með sér aukna hættu á fylgikvillum, meðal annars meira blóðtap, skurð í legháls, lengri sjúkrahúsdvöl og eykur einnig hættu á legbresti ef konan verður punguð aftur. ${ }^{15}$

Megintilgangur pessarar rannsóknar var að afla upplýsinga um tíðni fylgikvilla við keisaraskurði á Landspítala og athuga hvort munur væri á tíðni fylgikvilla eftir pví á hvaða stigi fæðingaraðgerðin var gerð. Pessar upplýsingar geta meðal annars nýst heilbrigðisstarfsfólki við ráðgjöf til verðandi mæðra pegar verið er að ræða um kosti og galla 
Tafla I. Pýði rannsóknar.

\begin{tabular}{lccc}
\hline & Miððgildi (mörk) & Neðri fjórðungsmörk & Efri fjórðungsmörk \\
\hline Aldur (ár) & $30(16-49)$ & 26 & 34 \\
\hline Líkamspyngdarstuðull (kg/m2) & $25,3(16,9-50,1)$ & 28 & 41 \\
\hline Meðgöngulengd (vikur) & $39,3(24,8-42,2)$ & 38,3 & 40,6 \\
\hline
\end{tabular}

Tafla II. Upplýsingar um gang við og eftir aðgerð.

\begin{tabular}{lccc}
\hline & Miðgildi (mörk) & Neðri fjórðungsmörk & Efri fjórðungsmörk \\
\hline Lengd aðgerðar (mínútur) & $34(7-90)$ & 28 & 41 \\
\hline Lengd sjúkrahúsdvalar (dagar) & $4(1-31)$ & 4 & 5 \\
\hline Lækkun í blóðrauða (g/L) & $14(-7-59)$ & 8 & 22
\end{tabular}

mismunandi fæðingarmáta. Ennfremur má líta á rannsóknina sem fagrýni sem nota má til að bæta vinnulag við keisaraskurði og fækka fylgikvillum.

\section{Efniviður og aðferðir}

Við framkvæmd rannsóknarinnar voru skoðaðar sjúkra- og mæðraskrár peirra kvenna sem fæddu einbura eða tvíbura með keisaraskurði á Landspítala frá 1. júlí 2001 til 31. desember 2002 (n=761). Upplýsingum var safnað um móður, aðgerð og sængurlegu og eftirfarandi upplýsingar skráðar: Aldur móður, pyngdarstuðull, meðgöngulengd, hvort hún hafði áður fætt með keisaraskurði, mismunur á blóðrauðagildi fyrir og eftir aðgerð, tegund og lengd aðgerðar, tegund deyfingar, hvort sýklalyf voru gefin, hvernig fylgjan fæddist og peir fylgikvillar sem upp komu 1 aðgerð eða eftir. Ef móðir fékk hita yfir $38^{\circ} \mathrm{C}$ á fyrsta sólarhring eftir fæðingu var pað skráð sem fylgikvilli, jafnvel pó ekki væri um klíníska sýkingu að ræða. Keisaraskurðir voru flokkaðir á eftirfarandi hátt:

1. Valaðgerð eða bráðaaðgerð framkvæmd áður en sótt hófst

2. Bráðakeisaraskurður á 1. stigi fæðingar (útvíkkunarstig)

3. Bráðakeisaraskurður á 2. stigi fæðingar (rembingsstig) án undangenginnar tilraunar til áhaldafæðingar

4. Bráðakeisaraskurður á 2. stigi fæðingar eftir að áhaldafæðing hefur verið reynd

5. Neyðarkeisaraskurður
Upplýsingum var safnað í töflureikni og pær síðan fluttar í tölfræðiforritin SPSS og JMP. Lýsandi tölfræði var notuð til að lýsa niðurstöðunum, meðal annars með tíðnitölum, tíðnitöflum, meðaltölum og miðgildum eftir pví sem við átti. Við samanburð á flokkunarbreytum var notað kíkvaðrat próf eða Fisher's exact próf eftir pví sem við átti. Mann-Whitney próf var notað par sem dreifing var skekkt. Kendall's tau próf var notað til að reikna styrkleika (marktækni) á fylgni milli tveggja raðgilda. Við mat á tölfræðilegri marktækni var miðað við $\mathrm{p}<0,05$.

Fengin voru viðeigandi leyfi hjá siðanefnd Landspítala, Persónuvernd og sviðsstjóra kvennasviðs Landspítala.

\section{Niðurstöður}

Upplýsingar um pýði rannsóknarinnar má sjá í töflu I. Alls höfðu 225 af 761 konu áður fætt með keisaraskurði (29,6\%). Fylgikvillar komu upp hjá 260 konum af 761, pað er hjá 35,5\% kvennanna. Niðurstöður um rannsóknarpýðið og tíðni fylgikvilla eru sýndar í töflum II og III.

Flokkar keisaraskurða. Marktækur munur var á pörf á blóðgjöf, hita eftir aðgerð, rifu frá legskurði og meðallækkun í blóðrauða eftir flokki keisaraskurðar, sjá töflu IV. Ekki kom fram marktækur munur á blóðtapi, pörf á enduraðgerð eða tíðni sýkinga. Tíðni fylgikvilla var lægst hjá peim konum sem fóru í valaðgerð en hæst pegar keisaraskurður var framkvæmdur eftir að fullri útvíkkun var náð.

Sýklalyfjagjöf. Fyrirbyggjandi sýklalyfjagjöf var gefin í 80,1\% tilvika. Hún hafði verndandi áhrif gagnvart sýkingu í skurðsári par sem 4,9\% peirra sem ekki fengu sýklalyf fengu sýkingu í skurðsár en einungis $1,2 \%$ peirra sem fengu sýklalyf $(p<0,01)$. Ekki kom fram marktækur munur eftir pví hvort konur fengu sýklalyf eða ekki á hita eftir aðgerð $(p=0,32)$, sýkingu í legi $(p=0,55)$ eða pvagfærasýkingu ( $\mathrm{p}=0,79)$.

Aldur móður. Hiti eftir aðgerð var algengari með hækkandi aldri móður (Kendall’s fylgni jákvæð við 0,05 stig) og einnig var fylgni milli aukins aldurs móður og lengri aðgerðartíma (Kendall'sfylgni jákvæð við 0,01 stig). Hins vegar reyndist ekki vera fylgni milli aldurs og lækkunar á blóðrauða, parfar á blóðgjöf, lengdar sjúkrahúsdvalar eða sýkinga í skurðsári, legi eða pvagfærum.

Líkamspyngdarstuðull. Eftir pví sem líkamspyngdarstuðull var hærri hjá konum, peim mun lengri tíma tók aðgerð (Kendall's fylgni marktæk við 0,01 stig). Ekki reyndist vera fylgni milli líkamspyngdarstuðuls og lækkunar á blóðrauða, parfar 
á blóðgjöf, lengdar sængurlegu, hita í sængurlegu eða sýkingar í skurðsári, legi eða pvagfærum. Ekki var marktæk fylgni með hækkandi pyngdarstuðli samhliða hækkandi aldri pó viss tilhneiging væri í pá átt $(\mathrm{p}=0,055)$.

Fylgjufæðing. Pegar fylgjan var látin fæðast sjálfkrafa voru meiri líkur á sýkingu í skurðsár $(3,1 \%, n=12)$ samanborið við pau tilfelli par sem fylgjan var sótt $(0,3 \%, n=1), p=0,02$. Pegar fylgjan var sótt voru oftar gefin sýklalyf samanborið við pann hóp par sem fylgjan var látin fæðast sjálfkrafa, p=0,0043 og gæti pað skýrt pennan mun að einhverju leyti. Ekki kom fram marktækur munur á blóðtapi, pörf á blóðgjöf eða sýkingu í legi eftir pví hvernig fylgjan fæddist.

Meðhöndlun legs. Hjá 28,1\% kvennanna var leg tekið út úr kvið á meðan pað var saumað. Ekki var tölfræðilega marktækur munur á hita í sængurlegu $(\mathrm{p}=0,68)$, sýkingu í skurðsári $(\mathrm{p}=0,55)$ eða legi $(\mathrm{p}=0,52)$, pvagfærasýkingu $(\mathrm{p}=0,34)$, áætluðu blóðtapi $(p=0,10)$, blóðtapi $\geq 1000 \mathrm{ml}(\mathrm{p}=0,07)$ eða lækkun í blóðrauða $(\mathrm{p}=0,58)$ eftir pví hvort leg var tekið út í aðgerð eða ekki.

Enduraðgerð. Pær konur sem purftu að fara í enduraðgerð lækkuðu meira í blóðrauða heldur en aðrar konur $(\mathrm{p}=0,02)$ og purftu frekar á blóðgjöf að halda $(p<0,01)$. Рað kemur ekki á óvart í ljósi pess að blæðing sem ekki stöðvaðist sjálfkrafa var helsta ástæða enduraðgerðar. Ekki var tölfræðilega marktækur munur á áætluðu blóðtapi í upphaflegri aðgerð $(p=0,96)$ samanborið við aðrar konur né heldur voru fleiri sem voru taldar blæða $>1000 \mathrm{ml}(\mathrm{p}=0,99)$ í aðgerð.

T-skurður í leg. Pegar T-skurður var gerður î leg $(n=7)$ var aðgerðartími lengri $(p=0,03)$. Einn sjúklingur fékk sýkingu í skurðsár en par sem um fáa einstaklinga er að ræða er vart hægt að reikna tíðni né marktækni. Konur sem hlutu T-skurð í leg voru með tölfræðilega marktækt hærri líkamspyngdarstuðul en aðrar konur $(\mathrm{p}<0,01)$. Ekki var tölfræðilega marktækur munur á meðgöngulengd
Tafla III. Tiðni fylgikvilla við keisaraskurði.

\begin{tabular}{lcc}
\hline & Fjöldi / heildarfjöldi & Tíðni (\%) \\
\hline Blóðtap $\geq 1000 \mathrm{ml}$ & 124 / 733 & 16,9 \\
\hline Hiti í sængurlegu $\left(\geq 38^{\circ} \mathrm{C}\right)$ & 89 / 729 & 12,2 \\
\hline Rifa frá legskurði niður & $55 / 759$ & 7,2 \\
\hline Pörf á blóðgjöf & $33 / 761$ & 4,3 \\
\hline Sýking í skurðsári & $14 / 729$ & 1,9 \\
\hline Höfuðverkur í kjölfar mænudeyfingar & $12 / 730$ & 1,6 \\
\hline Enduraðgerð & $11 / 734$ & 1,5 \\
\hline Garnalömun (ileus) & $7 / 730$ & 1 \\
\hline T-skurður í leg & $7 / 730$ & 1 \\
\hline Sýking í legi & $7 / 729$ & 0,5 \\
\hline Pvagfærasýking & $4 / 729$ & 0,3 \\
\hline Væg garnalömun (subileus) & $2 / 730$ & 0,3 \\
\hline Lungnabólga & $2 / 730$ & 0,1 \\
\hline Legnám eftir aðgerð & $1 / 730$ & 0,1 \\
\hline Skaði á pvagblöðru & $1 / 730$ & 1 \\
\hline
\end{tabular}

Sumar konur luku sængurlegu annars staðar en á Landspítala og einnig kom fyrir að aðgerðarlýsingu eða svæfingarblað vantaði, pví eru mismunandi nefnarar eftir pví hversu margar konur höfðu fullnægjandi gögn til að meta viðkomandi fylgikvilla. Vert er að hafa í huga að hver kona getur haft fleiri en einn fylgikvilla.

( $\mathrm{p}=0,21)$ eftir pví hvort gera purfti T-skurð í leg eða ekki.

Lengd aðgerðar. Aðgerð tók lengri tíma hjá peim konum sem höfðu áður farið í keisaraskurð en meðalaðgerðartími var 37,5 mínútur en 33,9 mínútur hjá peim sem fóru í sinn fyrsta keisaraskurð. (Kendall's fylgni marktæk við 0,01 stig), hjá peim konum sem fengu rifu niður frá legskurði (Kendall's fylgni marktæk við 0,01 stig) og hjá peim sem purftu á blóðgjöf að halda í kjölfar aðgerðar (Kendall's fylgni marktæk við 0,05 stig).

Legnám. Ein kona í rannsókninni purfti að fara í legnám í kjölfar keisaraskurðar. Stjórnlaus blæðing varð í aðgerðinni sem leiddi til storkutruflana sem kröfðust blóð- og blóðhlutagjafa og reyndist legnám óhjákvæmilegt til að stöðva blæðingu.

Segavörn. Engin kona í rannókninni fékk bláæðasega. Alls fengu 744 konur af 761 (97,8\%) blóðpynningu eftir aðgerðina.

Tafla IV. Tíðni fylgikvilla eftir flokkum keisaraskurða.

\begin{tabular}{|c|c|c|c|c|c|c|}
\hline & $\begin{array}{c}\text { Valaðgerð } n=274 \\
(36,0 \%)^{\star}\end{array}$ & $\begin{array}{l}\text { Aðgerð á 1. stigi } \\
\text { fæðingar } n=424 \\
\qquad(55,7 \%)^{\star}\end{array}$ & $\begin{array}{c}\text { Aðgerð á 2. stigi } \\
\text { fæðingar án tilraunar til } \\
\text { áhaldafæðingar } n=36 \\
(4,7 \%)^{\star}\end{array}$ & $\begin{array}{c}\text { Aðgerð á 2. stigi } \\
\text { fæðingar eftir tilraun til } \\
\text { áhaldafæðingar.n=20 } \\
(2,6 \%)^{\star}\end{array}$ & $\begin{array}{c}\text { Neyðar aðgerð } \\
n=7(0,9 \%)^{\star}\end{array}$ & p-gildi \\
\hline Blóðgjöf & $\underline{2,6 \%}(\mathrm{n}=7 / 274)$ & $4,5 \%(n=19 / 424)$ & $5,6 \%(n=2 / 36)$ & $\underline{20,0 \%}(\mathrm{n}=4 / 20)$ & $14,3 \%(n=1 / 7)$ & 0,003 \\
\hline Hiti í sængurlegu & $\underline{3,5 \%}(\mathrm{n}=9 / 257)$ & $16,8 \%(n=69 / 410)$ & $\underline{19,4 \%}(n=7 / 36)$ & $15,0 \%(n=3 / 20)$ & $16,7 \%(n=1 / 6)$ & $<0,001$ \\
\hline Rifa frá legskurði & $\underline{2,6 \%}(\mathrm{n}=7 / 273)$ & $8,3 \%(n=35 / 423)$ & $\underline{22,2 \%}(\mathrm{n}=8 / 36)$ & $20,0 \%(n=4 / 20)$ & $14,3 \%(n=1 / 7)$ & $<0,001$ \\
\hline Meðallækkun í blóðrauða (g/L) & $\underline{12,6}$ & 16,5 & 23,3 & $\underline{24,2}$ & 17,7 & $<0,001$ \\
\hline Blóðtap $\geq 1000$ ml & $15,2 \%(n=41 / 270)$ & $17,9 \%(n=72 / 403)$ & $11,8 \%(n=4 / 34)$ & $26,3 \%(n=5 / 19)$ & $28,9 \%(n=2 / 7)$ & 0,842 \\
\hline Enduraðgerð & $1,5 \%(n=4 / 261)$ & $1,7 \%(n=7 / 411)$ & $0 \%(n=0 / 36)$ & $0 \%(n=0 / 20)$ & $0 \%(n=0 / 6)$ & 0,9 \\
\hline
\end{tabular}

Marktækur munur var á peim flokkum par sem undirstrikað er.

Fyrir neðan tíðnitölu viơkomandi fylgikvilla sést hversu margir fengu hann af peim fjölda par sem upplýsingar um gang í aðgerð og sængurlegu lágu fyrir.

*Tíoni viðkomandi flokks af heildarfjölda keisaraskurða. 


\section{Umræða}

Tiððni fylgikvilla

Af peim konum sem fóru í keisaraskurð á Landspítala fengu $35,7 \%$ peirra fylgikvilla ef með voru taldir fylgikvillarnir garnalömun, væg garnalömun og höfuðverkur í kjölfar mænudeyfingar, en í erlendum rannsóknum eru peir oft undanskildir. Ef peir eru ekki taldir með fengu 35,5\% kvennanna fylgikvilla. Í erlendum rannsóknum hefur tíðni fylgikvilla verið lýst frá 21,4\% til $35,7 \%{ }^{5,6}$ og eru niðurstöður pessarar rannsóknar pví svipaðar. Blóðtap $\geq 1000 \mathrm{ml}$ reyndist vera 16,9\% en pað hefur reynst vera 1,5-9,2\% í erlendum rannsóknum og tíðnin pví hærri hér. 5, 6, 8, 12, 16 Möguleg skýring er að mismunandi aðferðir eru notaðar við að meta blóðtap. Í keisaraskurði á Landspítala er blóðtap metið út frá peim vökva sem safnast í sog og dúka við aðgerðina en legvatn getur truflað petta mat. Pegar aðgerðarlæknar meta blóðtap reikna sumir eingöngu pað blóð sem er í sogi, dúkum og grisjum en aðrir taka einnig með pað blóð sem er í fylgjunni. Pörf á enduraðgerð var 1,5\% sem er svipað og lýst hefur verið í erlendum rannsóknum par sem tíðnin hefur reynst vera $0,1 \%-1,9 \% .^{5,6,8}$

peir fylgikvillar sem voru sjaldgæfari á Landspítala en í erlendum rannsóknum voru sýking í legi, pvagfærasýking og blóðsegamyndun. Sýking í legi var 1,0\% hér en hefur í öðrum rannsóknum reynst vera frá 3,0\%-14,1\%.8, 9 Tíðni pvagfærasýkinga var $0,5 \%$ en hefur hún reynst vera 1,2-19\% í öðrum rannsóknum., 7-9 Möguleg skýring á lágri tíðni sýkinga í legi og pvagfærasýkinga er vanskráning. Einnig er vert að hafa í huga að hjá peim konum sem fóru snemma heim og komu síðar á göngudeild með sýkingu í legi eða skurðsári gæti skráning um pá komu verið annars staðar í sjúkraskránni en í mæðraskránni og pví hafi pær upplýsingar ekki komið fram í rannsókninni. Engin kona í rannsókninni fékk blóðsega og kemur pað ekki á óvart par sem hann er sjaldgæfur fylgikvilli og pyrfti úrtakið í rannsókninni að vera mun stærra til að hægt væri að meta tíðni blóðsega. Tíðni segamyndunar í bláæðum hefur reynst vera á bilinu 0,1-2\% í erlendum rannsóknum. ${ }^{4,6,13}$ Ekki komu heldur fram í rannsókninni skaði á pörmum eða blóðrek í lungum sem eru pekktir en sjaldgæfir fylgikvillar í kjölfar keisaraskurðar.6, 12, 14 Tíðni annarra fylgikvilla sem fram komu í rannsókninni var í samræmi við erlendar rannsóknir. ${ }^{6-12}$

Aukinn pyngdarstuðull mæðra hefur verið tengdur við aukna áhættu á fylgikvillum við keisaraskurði, svo sem blóðtapi $\geq 1000 \mathrm{ml},{ }^{12}$ hækkuðum blóðprýstingi eftir aðgerð, áhrif á garnastarfsemi, ${ }^{17}$ sýkingu í skurðsári ${ }^{8,9}$ og sýkingu í legi. ${ }^{9}$ Einnig hafa komið fram rannsóknir par sem aukinn pyngdarstuðull mæðra virðist ekki vera áhættupáttur fyrir fylgikvillum við keisaraskurði ${ }^{5}$ og er mögulegt að aukin pykkt vefja undir húð á skurðsvæði sé sjálfstæður áhættupáttur fyrir sýkingu í skurðsári, án tengsla við pyngdarstuðul. ${ }^{12}$ Í pessari rannsókn reyndist aðgerðartími lengri eftir pví sem konur höfðu hærri líkamspyngdarstuðul við upphaf meðgöngu en hins vegar var ekki meiri hætta á blóðmissi, sýkingum eða öðrum fylgikvillum hjá pessum konum.

Samanburður á tíðni fylgikvilla milli mismunandi flokka keisaraskurða

Fylgikvillar eru mun algengari hjá konum ef keisaraskurður er gerður eftir að fullri útvíkkun er náð. Tíðni fylgikvilla er töluvert lægri ef keisaraskurður er gerður á fyrsta stigi fæðingar og lægst ef um valkeisaraskurð er að ræða. Ef keisaraskurðir eru einungis flokkaðir í valog bráðakeisaraskurði (bráðakeisaraskurðir ekki flokkaðir nánar) er tíðni allra fylgikvilla lægri við valkeisaraskurði en pókemur ekki fram marktækur munur á blóðgjöf eins og kom fram pegar valkeisaraskurður var borinn saman við aðgerð á 2. stigi fæðingar eftir að áhaldafæðing hefur verið reynd og neyðarkeisaraskurð. Í ljósi pessa parf að íhuga að ef á meðgöngu eru taldar miklar líkur á pví að fæðing endi með keisaraskurði á 2. stigi fæðingar er ef til vill öruggara fyrir móðurina að fæða með valkeisaraskurði. Vissulega getur pó verið erfitt að sjá fyrir hvort fæðing muni enda í bráðakeisaraskurði. Pegar keisaraskurðir eru gerðir eftir að útvíkkun legháls er lokið og jafnvel eftir tilraun til ádráttar, hefur fæðingarlæknirinn ekki annan valkost en að ljúka fæðingunni með keisaraskurði, jafnvel pótt ljóst sé að sú aðgerð hafi talsvert auknar líkur á fylgikvillum í för með sér.

Með pví að gefa fyrirbyggjandi sýklalyf má draga úr tíoni sýkinga í skurðsári, en ekki hita eftir aðgerð eða sýkingum í legi eða pvagfærum. Ekki skiptir máli varðandi blóðtap eða sýkingar hvort leg er tekið út í aðgerð eða ekki en vert er að benda á að 90\% peirra kvenna sem legið var tekið út úr í aðgerðinni fengu sýklalyf en $76 \%$ peirra kvenna sem legið var ekki tekið út úr í aðgerðinni og er tölfræðilega marktækur munur á hópunum $(p<0,01)$. Pessi munur á sýklalyfjagjöf skekkir pví samanburð á tíðnitölum sýkinga milli hópanna. Aðrir hafa sýnt fram á minna blóðtap með pví að taka leg út við aðgerð. ${ }^{18}$ 
Takmarkanir á rannsókninni

Fyrir kom að atriði voru ekki skráð í mæðraskrá kvenna, svo sem hæð eða pyngd og að upplýsingar vantaði til dæmis um áætlað blóðtap í aðgerð, gildi á blóðrauða fyrir eða eftir aðgerð og hvernig fylgjan var fjarlægð. Par sem rannsóknin er afturvirk er mögulegt að upplýsingar hafi að einhverju leyti verið vanskráðar, svo sem að kona hafi fengið sýklalyf í aðgerð en pað ekki skráð og að leg hafi verið tekið út í aðgerð en pað ekki skráð. Nákvæmari niðurstöður fyrir gjöf sýklalyfja og einnig á meðhöndlun legs mætti vissulega nálgast betur með framsýnni rannsókn en pví var ekki við komið að pessu sinni.

Gildi á blóðrauða eftir aðgerð var ekki alltaf mælt á sama tíma eftir aðgerð. Hjá flestum var pað mælt um sólarhring eftir aðgerð, en tíminn gat verið frá hálfum til tveimur sólarhringum eftir aðgerð. Einnig var mismunandi hversu löngu fyrir aðgerð blóðrauði var mældur, yfirleitt nokkrum klukkustundum fyrr.

Rannsóknin var námsverkefni eins höfundarins (HV) sem pá var læknanemi við læknadeild Háskóla Íslands.

\section{Niðurlag}

Keisaraskurður er algeng aðgerð sem almennt er talin hættulítil bæði af heilbrigðisstarfsfólki og almenningi. Tíðni fylgikvilla er pó umtalsverð par sem um priðjungur kvenna fær einhvern fylgikvilla í tengslum við keisaraskurð og eru meiri líkur á fylgikvilla ef um bráðaaðgerð er að ræða. Ekki er einungis hætta á fylgikvillum í tengslum við aðgerðina sjálfa heldur eru seinni tíma vandamál einnig aukin. Pannig er til dæmis talin vera aukin hætta á andvana fæðingu hjá peim konum sem hafa áður fætt með keisaraskurði. Skýringar á pví mætti hugsanlega rekja til verra æðakerfis í legi vegna örmyndunar, meiri hættu á óeðlilegri staðsetningu fylgju og verri proskun totuæðakerfis (villous tree) í fylgju..$^{19}$ Pá eru auknar líkur á inngróinni fylgju (placenta acreta) sem getur valdið stjórnlausri og lífshættulegri blæðingu við fæðingu auk pess sem líkur á legnámi við næstu fæðingu eru auknar. Keisaraskurðir eru heldur ekki hættulausir fyrir barnið pví auknar líkur eru á öndunarerfiðleikum ef valkeisaraskurður er gerður fyrir 39 vikur. ${ }^{20}$ Fyrir kemur að skorið er í húð barns pegar legskurður er framkvæmdur. ${ }^{21}$

Keisaraskurður er með algengustu aðgerðum sem framkvæmdar eru á Landspítala í dag. Pótt öryggi peirra sé sífellt að aukast parf pó ávallt að hafa í huga að engin aðgerð er án fylgikvilla og mikilvægt að ígrunda vel ábendingu fyrir aðgerð.

\section{Pakkir}

Pakkir fá Anna Haarde, skrifstofustjóri kvennasviðs Landspítala, Anna Björg Jónsdóttir, fyrrverandi skrifstofustjóri kvennasviðs Landspítala og Guðrún Garðarsdóttir, ritari Fæðingarskrár.

\section{Heimildir}

1. Skýrslur frá Fæðingarskráningu fyrir árin 1950, 1960, 1970, 1980, 1985, 1997-2004. Kvennadeild og vökudeild Barnaspítala Hringsins, Landspítala - Háskólasjúkrahúsi, 101 Reykjavík, 1950, 1997-2006.

2. Wagner M. Choosing caesarean section. Lancet 2000; 356: 1677-80.

3. Holler, Karin. 1.stk. kejsersnit, tak! En undersøgelse af "Maternal Request" som socio-kulturelt fænomen inden for obstetrikken i Danmark. Mastersritgerð við GynækologiskObstetrisk Afd. D, Odense Universitets Hospital; 2004.

4. Creasy RK, Resnik R, Iams JD. Maternal-fetal medicine: principles and practice. 5 ed. Saunders. Philadelphia 2004

5. Häger RM, Daltveit AK, Hofoss D, et al. Complications of cesarean deliveries: rates and risk factors. Am J Obstet Gynecol 2004; 190: 428-34.

6. Zelop C, Heffner LJ. The downside of cesarean delivery: short- and long-term complications. Clin Obstet Gynecol 2004; 47: 386-93.

7. Edi-Osagie EC, Hopkins RE, Ogbo V, et al. Uterine exteriorisation at caesarean section: influence on maternal morbidity. Br J Obstet Gynaecol 1998; 105: 1070-8.

8. Tran TS, Jamulitrat S, Chongsuvivatwong V, Geater A. Risk factors for postcesarean surgical site infection. Obstet Gynecol 2000; 95: 367-71.

9. Myles TD, Gooch J, Santolaya J. Obesity as an independent risk factor for infectious morbidity in patients who undergo cesarean delivery. Obstet Gynecol 2002; 100: 959-64.

10. Martens MG, Kolrud BL, Faro S, Maccato M, Hammill H. Development of wound infection or separation after cesarean delivery. Prospective evaluation of 2,431 cases. J Reprod Med 1995; 40: 171-5.

11. Vermillion ST, Lamoutte C, Soper DE, Verdeja A. Wound infection after cesarean: effect of subcutaneous tissue thickness. Obstet Gynecol 2000; 95: 923-6.

12. Bergholt T, Stenderup JK, Vedsted-Jakobsen A, Helm P, Lenstrup C. Intraoperative surgical complication during cesarean section: an observational study of the incidence and risk factors. Acta Obstet Gynecol Scand 2003; 82: 251-6.

13. Krebs L, Langhoff-Roos J. Elective cesarean delivery for term breech. Obstet Gynecol 2003; 101: 690-6.

14. Chisaka H, Utsunomiya H, Okamura K, Yaegashi N. Pulmonary thromboembolism following gynecologic surgery and cesarean section. Int J Gynaecol Obstet 2004; 84: 47-53.

15. Boyle JG, Gabbe SG. T and J vertical extensions in low transverse cesarean births. Obstet Gynecol 1996; 87: 238-43.

16. National institute for clinical excellence. Clinical guideline: caesarean section. www.nice.org.uk/pdf/ CG013NICEguideline.pdf / apríl 2004.

17. Loverro G, Greco P, Vimercati A, Nicolardi V, VarcaccioGarofalo G, Selvaggi L. Maternal complications associated with cesariean section. J Perinatal Med 2001; 29: 322-6.

18. Ramadani, H. Cesarean section intraooperative blood loss and mode of placental separation. Int J Gynecol Obstet 2004; 87: 114-8.

19. Smith GSC, Pell JP, Dobbie R. Caesarean section and risk of unexplained stillbirth in subsequent pregnancy. Lancet 2003; 362: 1779-84

20. Dónaldsson SF, Dagbjartsson A, Bergsteinsson H, Harðardóttir H, Haraldsson Á, Pórkelsson P. Öndunarörðugleikar hjá nýburum sem fæðast með valkeisaraskurði. Læknablaðið 2007; 93: 675-9.

21. Smith JF, Hernandez C, Wax JR. Fetal laceration injury at cesarean delivery. Obstet Gynecol 1997; 90: 344-6. 
F R A $Đ$ | G R E | N A R

R A N N S Ó K N

\section{Complications of cesarean deliveries}

Objective: The objective of the study was to determine the rate of complications which accompany cesarean sections at Landspitali University Hospital (LSH).

Material and methods: All deliveries by cesarean section from July 1st 2001 to December 31st 2002 were examined in a retrospective manner. Information was collected from maternity records regarding the operation and its complications if they occured, during or following the operation.

Results: During this period 761 women delivered by cesarean section at LSH. The overall complication rate was $35,5 \%$. The most common complications were; blood loss $\geq 1000 \mathrm{ml}$ (16.5\%), post operative fever (12.2\%),

extension from the uterine incision (7.2\%) and need for blood transfusion (4.3\%). Blood transfusion was most common in women undergoing cesarean section after attempted instrumental vaginal delivery (20\%). Fever and extension from the uterine incision were most common in women undergoing cesarean section after full cervical dilation without attempt of instrumental delivery $(19,4 \%)$. These complications were least likely to occur if the patient underwent an elective secarean section.

Conclusion: Complications following cesarean section are common, especially if labor is advanced. Each indication for an operative delivery should be carefully weighed and the patient informed accordingly.

Valgeirsdottir H, Hardardottir H, Bjarnadottir Rl.

Complications of cesarean deliveries. Icel Med J 2010; 96: 37-42.

Key words: complications, cesarean section.

Correspondence: Hildur Harðardóttir, hhard@landspitali.is

Barst 26. mars 2009, - sampykkt til birtingar 26. nóvember 2009. 